\title{
Article \\ Effect of Fertilisation on the Quality of Dried Coriander (Coriandrum sativum L.) and Lovage (Levisticum officinale)
}

\author{
Natalia Matłok ${ }^{1,2, *(\mathbb{D}}$, Józef Gorzelany ${ }^{1}$, Adam Figiel ${ }^{2}(\mathbb{B})$ and Maciej Balawejder ${ }^{3}(\mathbb{C}$ \\ 1 Department of Food and Agriculture Production Engineering, College of Natural Sciences, \\ University of Rzeszow, St. Zelwerowicza 4, 35-601 Rzeszów, Poland; gorzelan@ur.edu.pl \\ 2 Institute of Agricultural Engineering, Wroclaw University of Environmental and Life Sciences, \\ Chelmonskiego 37a, 51-630 Wroclaw, Poland; adam.figiel@upwr.edu.pl \\ 3 Department of Chemistry and Food Toxicology, College of Natural Sciences, University of Rzeszow, \\ St. Ćwiklińskiej 1a, 35-601 Rzeszów, Poland; maciejb@ur.edu.pl \\ * Correspondence: nmatlok@ur.edu.pl
}

check for updates

Citation: Matłok, N.; Gorzelany, J.; Figiel, A.; Balawejder, M. Effect of Fertilisation on the Quality of Dried Coriander (Coriandrum sativum L.) and Lovage (Levisticum officinale). Agriculture 2021, 11, 386. https://doi. org/10.3390/agriculture11050386

Academic Editor: Eva Johansson

Received: 29 March 2021

Accepted: 22 April 2021

Published: 25 April 2021

Publisher's Note: MDPI stays neutral with regard to jurisdictional claims in published maps and institutional affiliations.

Copyright: (C) 2021 by the authors. Licensee MDPI, Basel, Switzerland. This article is an open access article distributed under the terms and conditions of the Creative Commons Attribution (CC BY) license (https:/ / creativecommons.org/licenses/by/ $4.0 /)$.

\begin{abstract}
The study presents the effects of fertilisation on selected quality parameters of the dried material obtained from plants of lovage and coriander. During the crop production process, the plants were treated with two fertilisers containing substances potentially acting as elicitors. The dried material was obtained in course of a drying process carried out in optimum conditions and based on the CD-VMFD method which combines convective pre-drying (CD) at a low temperature $\left(40^{\circ} \mathrm{C}\right)$ with vacuum-microwave finish drying with the use of $240 \mathrm{~W}$ microwaves (VMFD). The quality of the dried material was evaluated through measurement of the total contents of polyphenols, total antioxidant potential (ABTS and DPPH method), and the profile of volatile compounds (headspace-solid phase microextractio-HS-SPME) as well as assessment of the colour. It was found that by applying first fertilisation (with organic components) it is possible to significantly increase the contents of both bioactive compounds and volatile substances responsible for the aroma. It was determined that the higher content of bioactive compounds was related to the composition of the first fertiliser, presumably the extract from common nettle. The study showed that the application of the first fertiliser contributed to enhanced quality parameters of the raw material obtained.
\end{abstract}

Keywords: coriander; lovage; fertilisation; total polyphenolic content; antioxidant activity; HS-SPME

\section{Introduction}

Developments in the production of herbaceous plants are, among others, linked with the search for sources of natural antioxidants. Plants rich in bioactive compounds, most importantly polyphenols, include lovage and coriander. Lovage (Levisticum officinale) is a herbaceous plant in the family Apiaceae. This is one of the largest families comprising many species of medicinal plants and herbs. Like lovage, the plants in this family are characterised by pungent, strong aroma resulting from the presence of the essential oils contributing to the properties of these plants [1]. The amount and the composition of the oil varied in different morphological parts of plants, and depend on the plant variety and conditions of growth. The main components identified in the oil contained in lovage plant roots include $\beta$-pinene, pentylcyclohexadiene and $\alpha$-pinene [2]. It has also been reported that lovage plant roots and leaves have high contents of phenolic compounds providing stimulation for the immune system and protection against inflammations. Furthermore, the bioactive compounds contained in lovage plants are beneficial in preventing numerous cardiovascular diseases and neurodegenerative disorders, including Alzheimer's disease [3-5].

On the other hand, coriander (Coriandrum sativum L.) a plant in the family Umbelliferae, because of its properties is widely used as a medicinal herb and for culinary purposes, as a seasoning. In this case, the herbal materials are produced from leaves and seeds. Coriander leaves contain a number of vitamins, e.g., C, A and B2 as well as valuable polyphenols, and 
they present high antioxidant activity which is directly associated with the total contents of phenols $[2,6]$. Coriander, mainly its seeds, contains a large quantity of essential oil, ranking among the 20 most common essential oils in the global market [7]. The oil is predominantly obtained from seeds and its main component is linalool $[8,9]$. Owing to its properties, the oil exhibits antimicrobial activity against selected pathogens and saprophytes, which suggests it may also be used as a disinfectant [10].

Cultivation of medicinal plants and herbs become more and more important as a source for high-quality herbal products to meet consumer and industrial demands [11]. However, the quality of such materials depends on numerous factors, such as the conditions of production, mainly including the soil fertilisation used. By applying adequately balanced fertilisation with the use of substances known for elicitation potentials, such as nettle extract, Jasmonic acid, or yeast extract it may be possible to enhance certain biological functions by increasing the production of phenolic compounds [2,6]. Furthermore, elicitors may also affect the biosynthesis of other groups of bioactive compounds, such as vitamins and pigments (chlorophylls and carotenoids), which consequently improve the organoleptic quality of the herbal material obtained, including its colour. The biosynthesis of these compounds is an element of the regulation of processes that take place in the cell in response to external threats (nettle extract containing resin acids, acetylcholine, histamine, serotonin and formic acid [7]. The biosynthesis of these compounds is an element of the regulation of processes that take place in the cell in response to external threats (nettle extract with resin acids, acetylcholine, histamine, serotonin and formic acid). Given the fact that herbs such as lovage and coriander are not only consumed fresh but also (or mainly) in a form of dried products, it is necessary to ensure their good final quality by applying optimum drying methods. The combined application of convective drying and vacuum-microwave finish drying (CD-VMFD) is one of the methods which make it possible to preserve relatively high contents of thermally labile compounds, such as polyphenols, antioxidants and vitamins. In accordance with this method, the initial drying process applied at a low temperature $\left(40{ }^{\circ} \mathrm{C}\right)$ is followed by finish drying performed with the use of $240 \mathrm{~W}$ microwaves [12].

Many studies are focusing on quality assessment of lovage and coriander plants, however, there is no information on cultivation methods making it possible to enhance the commercial quality of dried products obtained from these herbs.

Therefore, this study aimed to evaluate the effect of two fertilizers containing substances that may act as triggers on the content of bioactive substances and the composition of the volatile fraction in dried leaves of Coriandrum sativum L. and Levisticum officinale.

\section{Materials and Methods}

\subsection{Plant Materials and Pot Experiment}

The research material comprised lovage Levisticum officinale and coriander Coriandrum sativum L. plants produced in a pot experiment. A one-factor pot experiment was carried out in a greenhouse and applied a peat substrate with a $\mathrm{pH}$ of 5.5-6.5. The first fertilisation method involved the use of the extract of common nettle (Urtica dioica L.) (10 g 100 substrate $\left.^{-1}\right)$ and with horse manure $\left(20 \mathrm{~g} 100\right.$ substrate $\left.^{-1}\right)$ and nitrogen fertilisation in dose $0.15 \mathrm{~g} \mathrm{~N}_{\text {pots }}{ }^{-1}$ (Bioilsa N 12.5; NaturalCrop Poland Sp. z o.o., Warszawa, Poland). The nettle extract was obtained during the fermentation of $3 \mathrm{~kg}$ of plant material with $10 \mathrm{~L}$ of water. After two weeks of storage at $20^{\circ} \mathrm{C}$, the mixture was filtered. The second fertilisation method was based on nitrogen fertilisation in dose $0.15 \mathrm{~g} \mathrm{~N}$ pots $^{-1}$ (Ammonium nitrate). In each replication, the experimental unit contained a peat substrate with an area of $0.5 \mathrm{~m}^{2}$ and consisted of 32 pots with a capacity of $0.78 \mathrm{~L}$ each; in each of them, four seeds were planted at a depth of about $0.5 \mathrm{~cm}$. The humidity of the substrate used for growing coriander and lovage was maintained at $60 \%$ full water content (FWC). The experiment was carried out at a temperature of $25^{\circ} \mathrm{C}$. No crop protection products were carried out during the experiment. Harvesting was carried out six weeks after planting the seeds. Immediately after harvesting, the plant material (above-ground biomass) was combined dried (CPD $40{ }^{\circ} \mathrm{C}$-VMFD $240 \mathrm{~W}$ ) which involved convective drying $(\mathrm{CD})$ at a temperature of $40^{\circ} \mathrm{C}$, and vacuum-microwave 
finish drying with $240 \mathrm{~W}$ microwaves (VMFD). The ultimate water content in the dried herbs of lovage and coriander amounted to approx. $6 \%$. Subsequently, the dried material was subjected to chemical analyses measuring the total contents of polyphenols, antioxidant potential as well as composition of volatile fraction (HS-SPME).

\subsection{Methods of Drying and Modelling of Drying Kinetics}

The methodologies detailed in the Supplementary Materials (S1,S2, Table S1) were applied to drying methods and the modelling of drying kinetics.

\subsection{Bioactive Compounds Content, Chemical Composition of HS-SPME and Colour}

The methodologies described in the Supplementary Materials (S3-S8) were used to determine the polyphenol content in the dry matter of Coriandrum sativum L. and Levisticum officinale leaves, antioxidant potential, the composition of the strum fraction of roof tiles (HS-SPME) and leaf colour. The utilized analytical methods validation parameters: limit of quantification (LOQ) $0.503 \mu \mathrm{g} \mathrm{g}^{-1}$ of gallic acid, and the range of the calibration curve was $0-20 \mathrm{mg} \mathrm{g}^{-1}$ of gallic acid, the limit of ABTS quantification (LOQ) $0.043 \mu \mathrm{g}$ Trolox $\mathrm{cm}^{-3}$, and the range of the calibration curve was from $0-200 \mathrm{mg} \mathrm{g}^{-1}$ Trolox, limit of DPPH quantification (LOQ) $0.076 \mu \mathrm{g}$ Trolox $\mathrm{cm}^{-3}$, and the standard curve range was from 0-200 $\mathrm{mg} \mathrm{g}^{-1}$ of Trolox.

\subsection{Statistical Analysis}

Significance differences were tested using one-way analysis of variance, ANOVA test, $\alpha=0.05$ ) in STATISTICA 13.1 (StatSoft Polska, Krakow, Poland) software.

\section{Results and Discussion}

\subsection{The Kinetics of Drying}

Lovage and coriander plants, after application of the applied fertilizer, were subjected to combined drying (CPD $40{ }^{\circ} \mathrm{C}-\mathrm{VMFD} 240 \mathrm{~W}$ ). The use of microwave radiation results in obtaining dried material of better quality in a shorter time compared to convection drying (CD) [12] Shorter drying time of herbal plants using the CPD-VMFD method was also reported in the case of basil and oregano [13]. Dried lovage and coriander with a moisture content of approx. 5\%, regardless of the fertilisation method used, was obtained after $264 \mathrm{~min}$ of drying. The Page model value of the daring process is presented in the table (Tables S1 and S2). The Page model is often used as one of the best in terms of accuracy and analytical simplicity mathematical model.

\subsection{Bioactive Compounds Content and Colour}

Lovage and coriander are widely used as a seasoning, applied as a fresh or a dried product. In terms of their stability, dried products are highly practicable because they are available not only during the growing season. The quality of those herbs is dependent on the drying method applied. As shown by Stępień et al. [12], Matłok et al. [14] and Orphanides et al. [15], in many cases, it is possible to preserve the high quality of the product by applying a combined drying method. This way it is possible to retain relatively high contents of thermally labile compounds, such as polyphenols, antioxidants and vitamins. It was shown that the application of the drying agent at a temperature of $40{ }^{\circ} \mathrm{C}$ makes it possible to preserve the high content of the components affecting the quality while satisfactory technological parameters are maintained (Figure 1). Similar effects of those conditions for drying Pink Rock Rose (Cistus creticus L.) were observed. The highest content of polyphenols was obtained for dried raw material by the convectiv method at $40^{\circ} \mathrm{C}$. It should be noted that increasing the drying agent temperature by $20^{\circ} \mathrm{C}$ decreased the content of poligenols in the raw material by $66 \mathrm{mg} 100 \mathrm{~g}^{-1}$ [14]. T. The differences in the quantitative and qualitative composition of the bioactive compounds in the dried materials resulted only from the fertilisation applied in course of production. It was shown that first fertilisation significantly contributed to the increased total contents of polyphenols compared to the plants subjected 
to second fertilisation (Figure 2). As demonstrated by Matłok et al. [13] and Danilčenko et al. [16], components of first fertilisers, particularly nettle extract, beneficially impact the contents of these compounds. These extracts contain substances known for their potential as elicitors, that is why the application of these extracts as fertilisers may induce a response in the plant treated. Effects of such response include a number of biochemical processes resulting in the production of numerous groups of secondary metabolites, mainly polyphenols [17]. Furthermore, nitrogen contained in the fertiliser possibly produces effects reflected by the increased content of polyphenols in the raw plant material obtained. Components of plant fertilisers, mainly nitrogen, are important factors providing stimulation for secondary metabolism in the plants [18-20]. The effect of the applied fertilizers on the content of nutrients in the soil was presented in Supplementary Materials (S9, Table S2). Polyphenols affect the quality parameters of herbs subjected to drying, including their colour. This results from the fact that the majority of polyphenols are pigments.

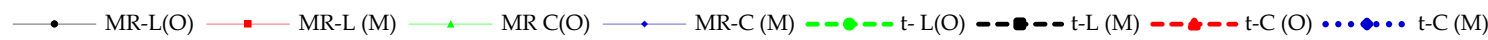

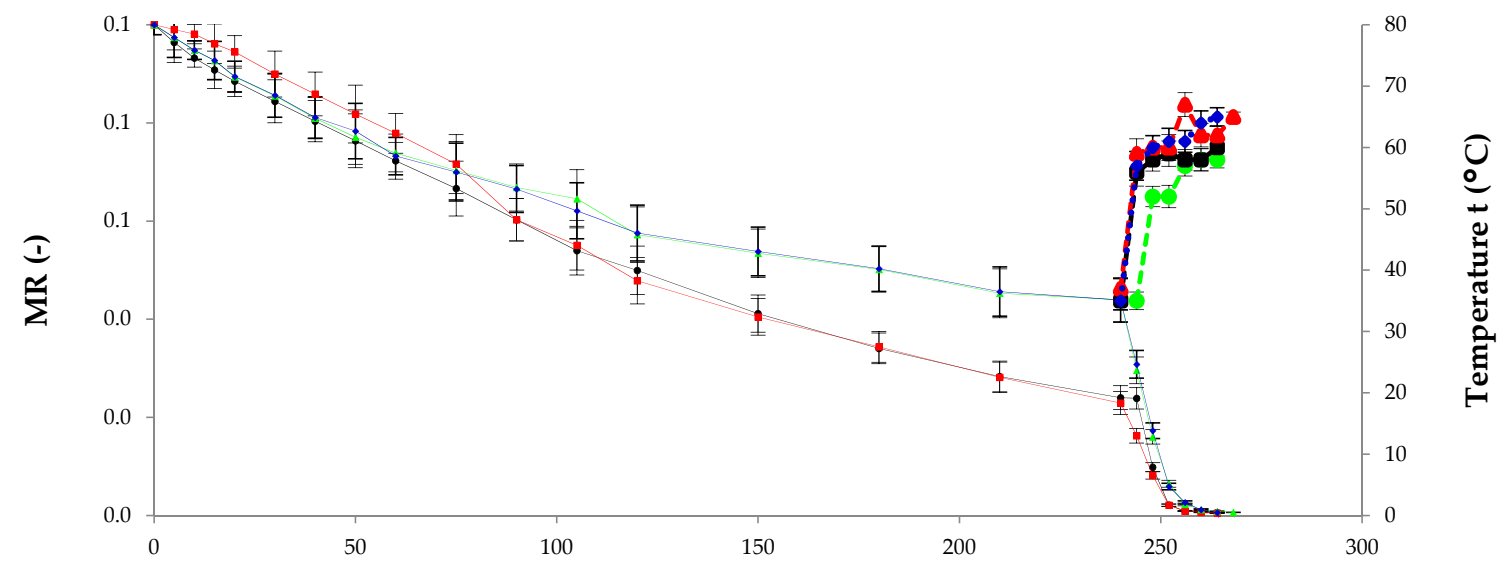

Time $\tau(\min )$

Figure 1. Water content decrease in Coriandrum sativum L. and Levisticum officinale plants during vacuum microwave drying after convection drying (CPD) at $40{ }^{\circ} \mathrm{C}$, followed by final vacuum microwave drying (VMFD). Note: MR = moisture ratio, $\mathrm{L}=$ lovage, $\mathrm{C}=$ coriander, $(\mathrm{O})=$ first fertilisation, $(\mathrm{M})=$ second fertilisation, $\mathrm{t}=$ temperature.

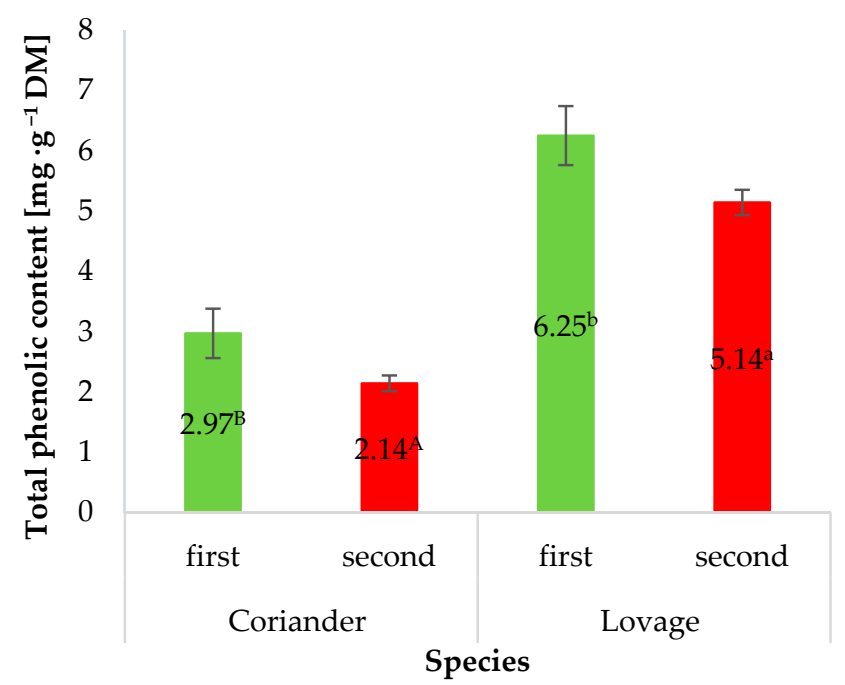

Figure 2. Total polyphenol content in the dry leaves of Coriandrum sativum L. and Levisticum officinale in relation to the fertilizer used. Differences in the results of polyphenol content are indicated by different letters. 
As shown in Table 1, the colour parameters of dried lovage and coriander plants, measured using $\mathrm{L}^{*} \mathrm{a}^{*} \mathrm{~b}^{*}$ method, are significantly different depending on the type of fertilisation applied during their production. Conditions of crop cultivation, including soil fertilisation applied, significantly affect the plant growth and biosynthetic pathways of secondary metabolites and photosynthetic pigments [21].

It was found that in terms of colour parameters, the dried materials were different depending on the fertilisation applied. There were differences in the proportional amount of green ( $\mathrm{a}^{*}$ parameter) which reflects the quality of the crop. The quality depends on the condition of the plants, and this can be measured with the content of green pigments, i.e., chlorophyll. The findings also show significant differences in the value of $b^{*}$ parameter whose increase is responsible for the proportional amount of yellow. Many compounds in the group of polyphenols, including quercetin and its glycosides, are yellow in colour. As suggested by evidence in the related literature [22,23], these herbs contain considerable quantities of these compounds. It can be hypothesised that an increase in this parameter and higher total contents of polyphenols may be indicative of increased content of that compound with confirmed bioactivity. However, the described mechanism could be different. The intensified content of yellow colour could be related to water loss during the drying, which can generate also carotenoids or other plant dyes. It should be noted that the drying conditions should not affect differences between colour parameters in plants fertilized with applied fertilizer [13]. The positive effect of the first fertilisation with nettle extract on the colour of dry material of oregano and basil plants was demonstrated in the studies of Matłok et al. [13,17].

Table 1. Assessment of the colour of dry leaves of Coriandrum sativum L. and Levisticum officinale in relation to the fertilizer used.

\begin{tabular}{ccccc}
\hline Species & Fertilisation Method & $\mathbf{L}^{*} \pm \mathbf{S D}$ & $\mathbf{a}^{*} \pm \mathbf{S D}$ & $\mathbf{b}^{*} \pm \mathbf{S D}$ \\
\hline \multirow{2}{*}{ Coriander } & first & $49.47 \pm 0.52^{\mathrm{a}}$ & $-0.28 \pm 0.06^{\mathrm{c}}$ & $13.08 \pm 0.40^{\mathrm{d}}$ \\
\cline { 2 - 4 } & second & $48.21 \pm 0.35^{\mathrm{a}}$ & $-0.23 \pm 0.21^{\mathrm{b}}$ & $12.23 \pm 0.68^{\mathrm{d}}$ \\
\hline \multirow{2}{*}{ Lovage } & first & $59.58 \pm 0.50^{\mathrm{A}}$ & $-2.42 \pm 0.08^{\mathrm{C}}$ & $12.28 \pm 0.20^{\mathrm{E}}$ \\
\cline { 2 - 4 } & second & $57.16 \pm 0.49^{\mathrm{A}}$ & $-1.98 \pm 0.19^{\mathrm{B}}$ & $10.46 \pm 0.31^{\mathrm{D}}$ \\
\hline
\end{tabular}

Note: \pm SD; $n=3$; differences between fertilisation methods, assessed by Statistica 13.1 ANOVA, Differences in the results of the colour of dry leaves of Coriandrum sativum L. are indicated by different lowercase letters and the difference between the colour of dry leaves of Levisticum officinale with different capital letters, difference at $p<0.05 . \mathrm{L}^{*}=$ brightness of a colour, $\mathrm{a}^{*}=$ proportion of green or red, $\mathrm{b}^{*}=$ proportion of blue or red-yellow.

It has been established that polyphenols contribute to the total antioxidant potential. This parameter, however, is also affected by other components of the raw material, e.g., vitamins, particularly those in the E group [15]. As shown in Figure 3, the application of first fertilisation resulted in the increased antioxidant potential of the dried materials produced. It was shown that the dried materials obtained from lovage and coriander plants treated with second fertiliser, had lower contents of the substances affecting the total antioxidant potential. The findings show that the potential measured using the ABTS method was approx. $4 \%$ higher in the dry material from lovage treated with first fertiliser, and over $6 \%$ in coriander (Figure 3A). It should be noted that the observed differences in standard deviations of the measured parameters are due to the natural variability of biological material. Similar relationships were observed when the potential was measured using the DPPH method (Figure 3B). The present findings suggest that by applying first fertilisers it is possible to enhance the radical scavenging capacity of Coriandrum sativum $\mathrm{L}$. and Levisticum officinale. An increase in the secondary metabolites and antioxidant activity in the dried materials obtained from lovage and coriander plants subjected to first fertilisation may be associated with the availability of various other primary and secondary elements contained in the organic and nutrient components of the fertiliser. Increased contents of antioxidants in plants treated with organic fertilisers, compared to the contents identified in plants treated with mineral fertilisers, were reported by numerous researchers. Increasing 
the content of this type of compounds is a typical response of plants to the presence of elicitors [17,24]. Ibrahim et al. [25] compared the effects of organic and non-organic fertilisation on the production of secondary metabolites and antioxidant activity of Kacip Fatimah plants (Labisia pumila Benth). They established that the application of chicken dung as organic fertiliser contributes to $7 \%$ higher antioxidant potential of the raw material, compared to the plants treated with second fertilisers.
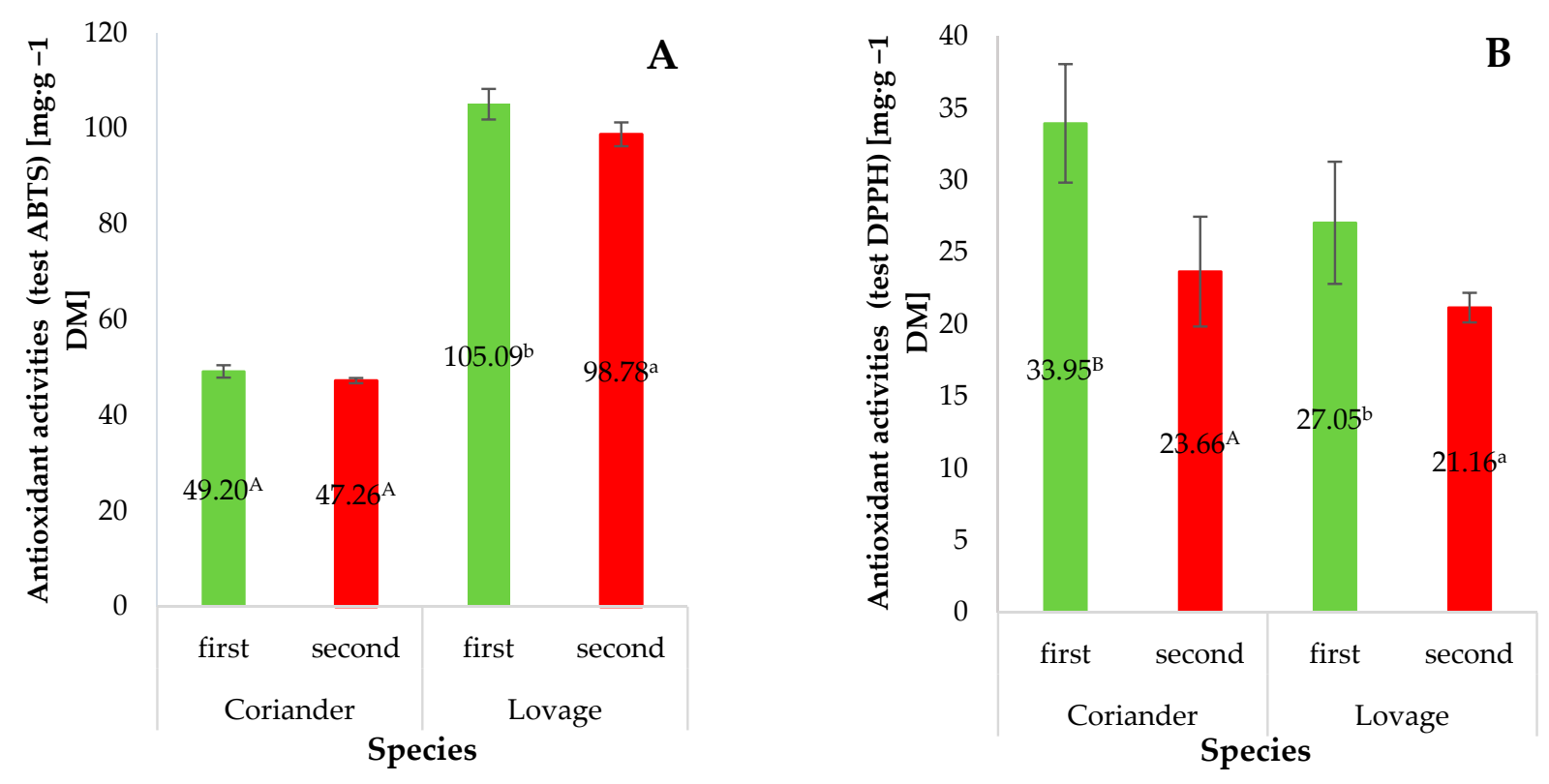

Figure 3. Antioxidant activities: ABTS test (A) and DPPH test (B) in dry leaves of Coriandrum sativum L. and Levisticum officinale relative to the fertilizer applied. Described as a Trolox equivalent. Note: $\pm \mathrm{SD} ; n=3$; differences between the fertilisation methods, assessed by Statistica 13.1 ANOVA test, Differences in the results between the assessment of colour in dry leaves of Coriandrum sativum L. are indicated by different capital letters, and difference between the assessment of colour in dry leaves of Levisticum officinale indicated by different lower capitals, difference at $p<0.05$.

\subsection{Head Space-Solid Phase Microextraction (HS-SPME) of Dried Herbs}

Coriander is a well-known oil-producing material. The main components of typical essential oil obtained from coriander biomass include camphor, geraniol, $\alpha$-pinene, $\beta$-terpinene, geranyl acetate, limonene and linalool [26,27]. However, its composition differs in various morphological parts of the plant, development stage [28] and depends on a number of factors, e.g., the genotype as well as soil and weather conditions during growth [29]. It was found that the content and composition of volatile compounds isolated from coriander fruit also depends on the type of fertilisation. It has been shown that the use of organic $\mathrm{N}$ fertilisation is beneficial to the fortification of bioactive compounds [26]. The use of nettle extract with an organic nitrogen source (Bioilsa N 12.5) may find application in organic farming. The present study shows similar dependencies, where significant differences were found in the composition of the volatile fraction of plants of the same species in relation to the fertilisation applied. The coriander plants treated during growth with the first fertiliser were found to contain a substantial level of compounds with high volatility, such as carvacrol and $\alpha$-terpinyl acetate (Table 2). A typical chromatogram presenting the coriander volatile compounds profile was presented in Figure 4. HS-SPME analysis significantly depends on the vapour pressure of the compounds over the plant material examined. The high content of the aforementioned compounds corresponds to their high pressure, and consequently, the scent perceived. It should be noted that the profile of the determined compounds was different in terms of typical essential oil composition mainly due to the differences in the method of their isolation (HS-SPME). Significant differences in the composition of essential oil and HS-SPME were also observed in Adenosma indianum 
plants [30]. Quick organoleptic assessment performed by the authors proved that the plants treated with the first fertiliser had a stronger aroma. A similar effect was observed in the case of lovage plants. This herb also has relatively high contents of aromatic compounds. The main components of oils include cymene [23] but the composition is dependent on habitat [31]. Analysis of volatile fraction composition in lovage plants showed that the applied first fertilisation resulted in a $49 \%$ increase in the content of cymene (Table 2). The typical composition of dried lovage volatile compounds was presented on a chromatogram (Figure 5). The quick sensory assessment showed that the aroma of dried lovage plants were stronger for plants produce with the first fertilisation method. These observations and HS-SPME analyses showed that lovage and coriander materials in course of production subjected to first fertilisation were characterised by better aroma, contributing to higher commercial quality of the final material.

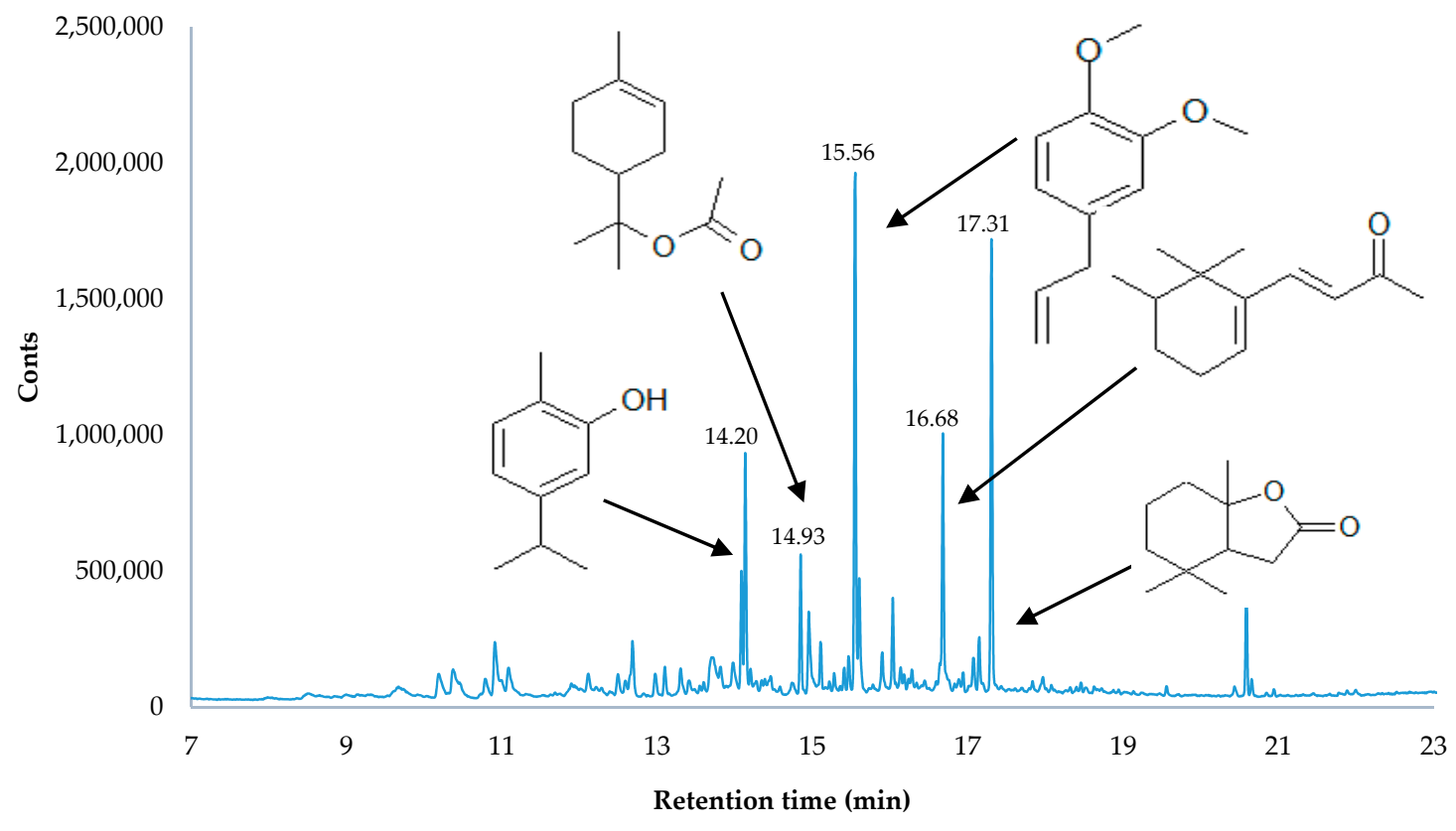

Figure 4. Chromatograms SPME-GC for the volatile fraction of dry material from Coriandrum sativum L.

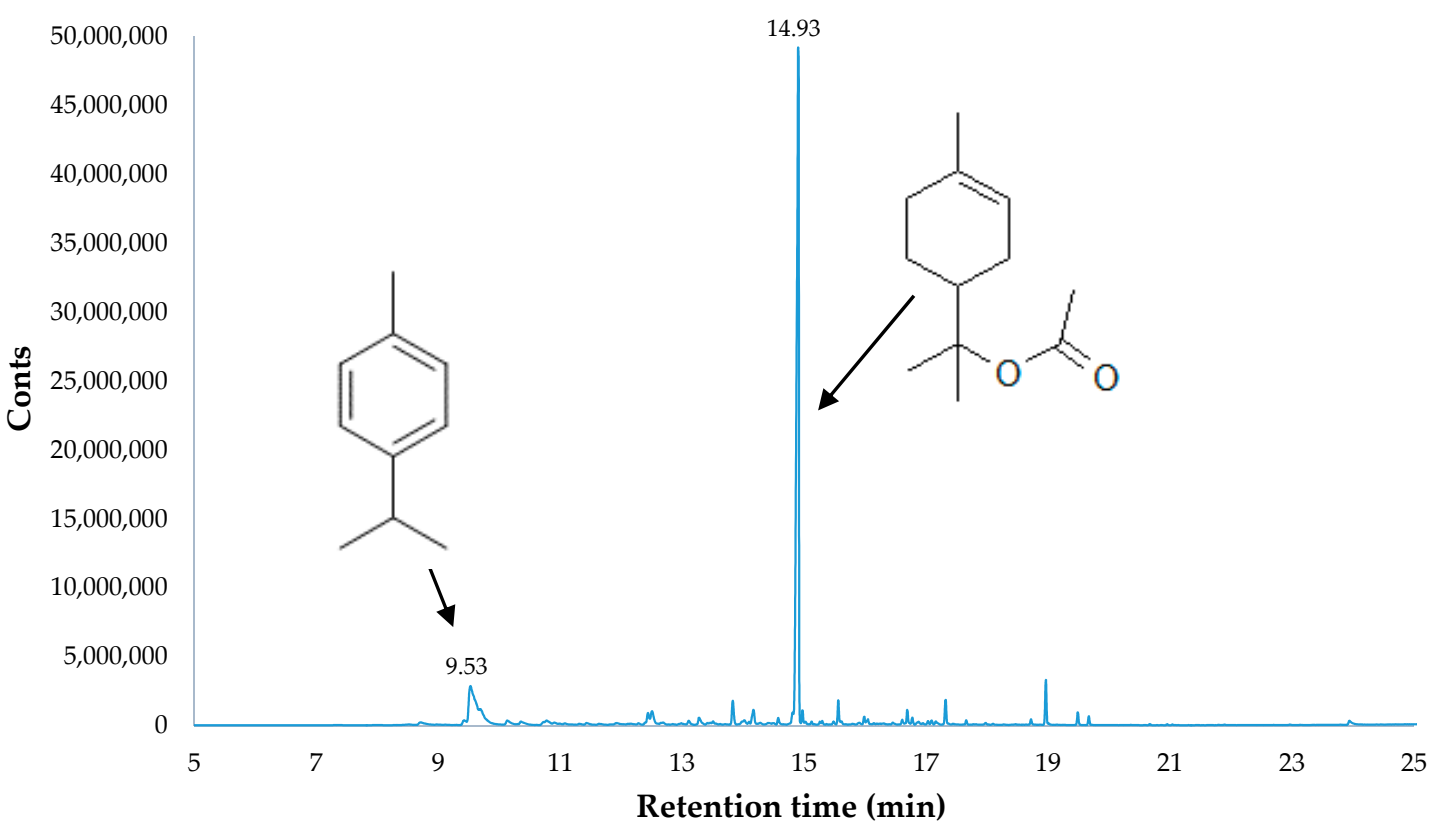

Figure 5. Chromatograms SPME-GC for the volatile fraction of dry material from Levisticum officinale. 
Table 2. Effect of the applied fertiliser on the chemical composition of headspace fractions of dry leaves of Coriandrum sativum L. and Levisticum officinale.

\begin{tabular}{|c|c|c|c|c|c|c|c|}
\hline \multirow{2}{*}{ No. } & \multirow{2}{*}{$\underset{(\min )}{\mathrm{RT}}$} & \multicolumn{4}{|c|}{ Peak Share in the Chromatogram [\%] } & \multirow{2}{*}{$\begin{array}{c}\text { Ordinary } \\
\text { Substance Name }\end{array}$} & \multirow{2}{*}{ Systematic Substance Name } \\
\hline & & $\mathrm{L}(\mathrm{O})$ & L(M) & $\mathrm{C}(\mathrm{O})$ & $\mathrm{C}(\mathrm{M})$ & & \\
\hline 1 & 9.53 & $12.58^{\mathrm{b}} \pm 2.11$ & $8.44^{\mathrm{a}} \pm 1.76$ & - & - & cymene & methyl(1-methylethyl)benzene \\
\hline 2 & 9.69 & $3.35^{\mathrm{b}} \pm 0.34$ & $2.44^{\mathrm{a}} \pm 0.12$ & - & - & $\beta$-phellandrene & 3-Isopropyl-6-methylenecyclohex-1-ene \\
\hline 3 & 10.16 & $0.87^{\mathrm{b}} \pm 0.16$ & $0.33^{\mathrm{a}} \pm 0.06$ & - & - & $\begin{array}{l}\text { trans-sabinene } \\
\text { hydrate }\end{array}$ & 2-methyl-5-propan-2-ylbicyclo[3.1.0]hexan-2-ol \\
\hline 4 & 10.37 & - & - & $4.25 \pm 1.38$ & trace & - & octa-3,5-dien-2-one \\
\hline 5 & 10.91 & - & - & trace & $3.78 \pm 0.97$ & linalool & 3,7-Dimethyl-1,6-octadien-3-ol \\
\hline 6 & 11.45 & trace & 0.43 & - & - & fenchol & 1,3,3-trimethylbicyclo[2.2.1]heptan-2-ol \\
\hline 7 & 12.45 & $0.76^{\mathrm{b}} \pm 0.14$ & $0.54^{\mathrm{a}} \pm 0.11$ & - & - & (-)-terpinen-4-ol & (1R)-4-methyl-1-propan-2-ylcyclohex-3-en-1-ol \\
\hline 8 & 12.51 & $1.41^{\mathrm{b}} \pm 0.23$ & $1.33^{\mathrm{a}} \pm 0.17$ & - & - & $\alpha$-terpinenol & 2-[(1S)-4-methyl-1-cyclohex-3-enyl]propan-2-ol \\
\hline 9 & 13.28 & $0.80^{\mathrm{a}} \pm 0.02$ & $0.59^{b} \pm 0.08$ & trace & trace & $\begin{array}{l}\text { carvacryl methyl } \\
\text { ether }\end{array}$ & 4-isopropyl-2-methoxy-1-methylbenzene \\
\hline 10 & 13.83 & $1.76^{\mathrm{b}} \pm 0.49$ & $0.91^{\mathrm{a}} \pm 0.31$ & trace & trace & phellandral & 4-propan-2-ylcyclohexene-1-carbaldehyde \\
\hline 11 & 14.06 & trace & $0.81 \pm 0.2$ & trace & 5.54 & thymol & 2-isopropyl-5-methylphenol \\
\hline 12 & 14.21 & $1.26^{\mathrm{b}} \pm 0.41$ & $0.68^{a} \pm 0.27$ & $13.47^{\mathrm{b}} \pm 1.26$ & $11.74^{\mathrm{a}} \pm 0.95$ & carvacrol & 2-methyl-5-(propan-2-yl)phenol \\
\hline 13 & 14.93 & $66.87^{\mathrm{a}} \pm 5.70$ & $75.35^{\mathrm{b}} \pm 3.32$ & $10.95^{\mathrm{b}} \pm 2.81$ & $6.28^{a} \pm 1.26$ & $\alpha$-terpinyl acetate & $( \pm)$-2-(4-Methyl-3-cyclohexenyl)isopropyl acetate \\
\hline 14 & 14.98 & - & - & $8.25 \pm 1.05$ & trace & eugenol & 2-methoxy-4-(2-propenyl)phenol \\
\hline 15 & 15.11 & - & - & $10.78 \pm 2.16$ & trace & piperitenone oxide & (1S)-1,2-epoxy-p-menth-4(8)-en-3-on \\
\hline 16 & 15.26 & trace & $0.31 \pm 0.07$ & - & - & lavandulyl acetate & (5-methyl-2-prop-1-en-2-ylhex-4-enyl) acetate \\
\hline 17 & 15.31 & $0.12^{\mathrm{a}} \pm 0.04$ & $0.28^{\mathrm{b}} \pm 0.06$ & - & - & $\alpha$-copaene & $\begin{array}{l}\text { 1,3-dimethyl-8-(1-methyl ethyl) } \\
\text { tricyclo(4.4.0.0.02,7-)dec-3-ene stereoisomer }\end{array}$ \\
\hline 18 & 15.56 & $1.16^{\mathrm{b}} \pm 0.31$ & $0.49^{\mathrm{a}} \pm 0.11$ & $13.65^{\mathrm{a}} \pm 2.98$ & $26.65^{b} \pm 6.87$ & methyl eugenol & $\begin{array}{l}\text { 4-Allyl-1,2-dimethoxybenzene, Eugenol methyl ether, } \\
\text { eugenyl methyl ether }\end{array}$ \\
\hline 19 & 15.60 & - & - & trace & $6.78 \pm 1.28$ & nothosyrnol & 1,3-bis(1-methoxyprop-1-enyl)benzene \\
\hline 20 & 15.98 & trace & trace & - & - & $\beta$-caryophyllene & $\begin{array}{l}\text { (-)-trans-caryophyllene, trans-(1R,9S)-8-Methylene- } \\
\text { 4,11,11-trimethylbicyclo[7.2.0]undec-4-ene }\end{array}$ \\
\hline 21 & 16.60 & trace & trace & - & - & $y_{\text {-muurolene }}$ & $\begin{array}{l}\text { (1R,4aR,8aS)-7-methyl-4-methylidene-1-propan-2-yl- } \\
\text { 2,3,4a,5,6,8a-hexahydro-1H-naphthalene }\end{array}$ \\
\hline 22 & 16.68 & $0.79^{\mathrm{a}} \pm 0.21$ & $0.77^{a} \pm 0.28$ & $9.97^{\mathrm{a}} \pm 2.64$ & $9.80^{a} \pm 3.71$ & (E)- $\beta$-ionone & $\begin{array}{l}\text { (E)-4-[(5R)-5,6,6-trimethylcyclohexen-1-yl]but- } \\
\text { 3-en-2-one }\end{array}$ \\
\hline 23 & 16.77 & trace & trace & - & - & $\beta$-selinene & $\begin{array}{l}\text { 28(3S,4aR,8aS)-8a-methyl-5-methylidene-3-prop-1-en- } \\
\text { 2-yl-1,2,3,4,4a,6,7,8-octahydronaphthalene }\end{array}$ \\
\hline \multirow[t]{2}{*}{24} & 17.31 & $1.59^{b} \pm 0.16$ & $0.93^{\mathrm{a}} \pm 0.11$ & $28.65^{b} \pm 2.07$ & $23.51^{\mathrm{a}} \pm 1.31$ & $\begin{array}{c}(S)- \\
\text { dihydroactinidiolide }\end{array}$ & $\begin{array}{l}\text { (2,6,6-trimethyl-2-hydroxycyclohexylidene)acetic } \\
\text { acid lactone }\end{array}$ \\
\hline & TOTAL & $93.32^{\mathrm{a}}$ & $94.63^{b}$ & $99.97^{b}$ & $93.81^{\mathrm{a}}$ & & \\
\hline
\end{tabular}

Note: $\mathrm{RT}=$ retention time, $\mathrm{L}=$ lovage, $\mathrm{C}=$ coriander, $(\mathrm{O})=$ first fertilisation, $(\mathrm{M})=$ second fertilisation; differences between the fertilisation methods, assessed by Statistica 13.1 ANOVA test, are indicated by different letters, difference at $p<0.05$ for 3 independent replication.

\section{Conclusions}

Dry materials obtained from lovage and coriander plants are valuable products used as a seasoning. It was shown that the quality of these products depends on the fertilisation applied during cultivation. The findings show that first fertilisation positively affects the quality of the final product. Due to the use of an organic source of nutrients, this modification can be used in organic farming. Improved quality is reflected by the increased total contents of secondary metabolism like polyphenols, total antioxidant potential and content of volatile compounds. The content of total polyphenols in dried lovage and coriander leaves fertilized with the first fertilisation increased compared to the second fertilisation by 38.8 and $21.6 \%$, respectively. The $4.1 \%$ (coriander) and $6.4 \%$ (lovage) increasing of ABTS antioxidant potential and $43.5 \%$ (coriander) and $27.8 \%$ (lovage) DPPH were observed. HS-SPME analysis determinate an increase in the content of compounds determining the smell of dried plant material. The improvement was also observed in the colour of the dried materials obtained. The changed colour parameters correlate with the contents of bioactive compounds, in particular pigments. It has been shown that the application of 
first fertilisation contributed to enhanced quality parameters of the raw material obtained by the elicitation process.

Supplementary Materials: The following are available online at https://www.mdpi.com/article/ 10.3390/agriculture11050386/s1. Materials and Methods: S1: Methods of Drying, S2: Modelling of Drying Kinetics, S3: Plant Extract, S4: Total Polyphenolic Content, S5: Antioxidant Activities (ABTS Method), S6: Colour Change, S7: Head Space-Solid Phase Microextraction HS-SPME, S8: Chromatographic Analysis, S9: Physico-chemical characteristics of the substratum. Table S1: The Page's model parameters, drying time and final water content in plants of Coriandrum sativum $\mathrm{L}$. and Levisticum officinale in combined drying $\left(\mathrm{CPD} 40^{\circ} \mathrm{C}\right.$-VMFD $\left.240 \mathrm{~W}\right)$ consisting of convective pre-drying at $40{ }^{\circ} \mathrm{C}(\mathrm{CPD})$ followed by vacuum-microwave finish drying at $240 \mathrm{~W}$ microwave power (VMFD); Table S2: The physico-chemical characteristics of the substraum relative to the fertilizer applied.

Author Contributions: Conceptualization, methodology, investigation and writing-original draft, N.M.; Investigation M.B., A.F.; Formal analysis, J.G. All authors have read and agreed to the published version of the manuscript.

Funding: The project is financed by the program of the Minister of Science and Higher Education named "Regional Initiative of Excellence" in the years 2019-2022, project number 026/RID/2018/19, the amount of financing PLN 9542 500.00.

Institutional Review Board Statement: Not applicable.

Informed Consent Statement: Not applicable.

Conflicts of Interest: The authors declare no conflict of interest.

\section{References}

1. Amiri, M.S.; Joharchi, M.R. Ethnobotanical knowledge of Apiaceae family in Iran, A review. Avicenna J. Phytomed. 2016, 6, 621-635.

2. Pedro, A.G.; Santosa, A.; Figueiredoa, M.C.; Oliveira, M.M.; Barroso, J.G.; Pedro, L.G.; Deans, S.G.; Schefferd, J.J.C. Growth and essential oil composition of hairy root cultures of Levisticum officinale W.D.J. Koch (lovage). Plant Sci. 2005, 168, 1089-1096. [CrossRef]

3. Nour, V.; Trandafir, I.; Cosmulescu, S. Bioactive Compounds, Antioxidant Activity and Nutritional Quality of Different Culinary Aromatic Herbs. Not. Bot. Horti Agrobot. Cluj-Napoca 2017, 45, 179-184. [CrossRef]

4. González, S.; Fernández, M.; Cuervo, A.; Lasheras, C. Dietary intake of polyphenols and major food sources in an institutionalised elderly population. J. Hum. Nutr. Diet. 2014, 27, 176-183. [CrossRef] [PubMed]

5. Sakulnarmrat, K.; Konczak, I. Composition of native Australian herbs polyphenolic-rich fractions and in vitro inhibitory activities against key enzymes relevant to metabolic syndrome. Food Chem. 2012, 134, 1011-1019. [CrossRef] [PubMed]

6. Kahkonen, M.P.; Hopia, A.I.; Vuorela, H.J.; Rauha, J.P.; Pihlaja, K.; Kujala, T.S. Antioxidant activity of plant extracts containing phenolic compounds. J. Agric. Food Chem. 1999, 47, 3954-3962. [CrossRef] [PubMed]

7. Diederichsen, A. Coriander. Promoting the conservation and use of underutilized and neglected crops, 3. In Spices; Purseglove, J.W., Brown, E.G., Green, C.L., Robbins, S.R.J., Eds.; Longman: New York, NY, USA, 1996; Volume 2, pp. 736-788.

8. Gil, A.; De La Fuente, E.B.; Lenardis, A.E.; Lopez Pereira, M.; Suarez, S.A.; Bandoni, A. Coriander essential oil composition from two genotypes grown in different environmental conditions. J. Agric. Food Chem. 2002, 50, 2870-2877. [CrossRef]

9. Grosso, C.; Gerraro, V.; Figueiredo, A.C.; Barroso, J.G.; Coelho, J.A.; Palavara, A.M. Supercritical carbon dioxide extraction of volatile oil from Italian coriander seeds. Food Chem. 2002, 111, 197-203. [CrossRef]

10. Elgayyar, M.; Draughon, F.A.; Golden, D.A.; Mount, J.R. Antimicrobial activity of essential oils from plants against selected pathogenic and saprophytic microorganisms. J. Food Prot. 2001, 64, 1019-1024. [CrossRef] [PubMed]

11. Canter, P.; Thomas, H.; Ernst, E. Bringing medicinal plants into cultivation: Opportunities and challenges for biotechnology. Trends Biotechnol. 2005, 23, 180-185. [CrossRef]

12. Stępień, A.E.; Gorzelany, J.; Matłok, N.; Lech, K.; Figiel, A. The effect of drying methods on the energy consumption, bioactive potential and colour of dried leaves of Pink Rock Rose (Cistus creticus). J. Food Sci. Technol. 2019, 56, 2386-2394. [CrossRef] [PubMed]

13. Matłok, N.; Gorzelany, J.; Stępień, A.E.; Figiel, A.; Balawejder, M. Effect of Fertilization in Selected Phytometric Features and Contents of Bioactive Compounds in Dry Matter of Two Varieties of Basil (Ocimum basilicum L.). Sustainability 2019, 11, 6590. [CrossRef]

14. Matłok, N.; Lachowicz, S.; Gorzelany, J.; Balawejder, M. Influence of Drying Method on Some Bioactive Compounds and the Composition of Volatile Components in Dried Pink Rock Rose (Cistus creticus L.). Molecules 2020, 25, 2596. [CrossRef]

15. Orphanides, A.; Goulas, V.; Geka, V. Drying Technologies: Vehicle to High-Quality Herbs. Food Eng. Rev. 2016, 8, 164-180. [CrossRef] 
16. Danilčenko, H.; Dabkevičius, Z.; Jarienè, E.; Tarasevičienè, Ž.; Televičiūtè, D.; Amošiūnas, A.; Jeznach, M. The effect of stinging nettle and field horsetail extracts on the synthesis of biologically active compounds in germinated leguminous and quinoa seed. Zemdirbyste-Agriculture 2017, 104, 337-344. [CrossRef]

17. Matłok, N.; Stępień, A.E.; Gorzelany, J.; Wojnarowska-Nowak, R.; Balawejder, M. Effects of Organic and Mineral Fertilization on Yield and Selected Quality Parameters for Dried Herbs of Two Varieties of Oregano (Origanum vulgare L.). Appl. Sci. 2020, 10, 5503. [CrossRef]

18. De Pascale, S.; Maggio, A.; Pernice, R.; Fogliano, V.; Barbieri, G. Sulphur fertilization may improve the nutritional value of Brassica rapa L. subsp sylvestris. Eur. J. Agron. 2007, 26, 418-424. [CrossRef]

19. Li, J.; Zhu, Z.; Gerendas, J. Effects of nitrogen and sulfur on total phenolics and antioxidant activity in two genotypes of leaf mustard. J. Plant Nutr. 2008, 31, 1642-1655. [CrossRef]

20. Barroso, M.R.; Martins, N.; Barros, L.; Antonio, A.L.; Rodrigues, M.A.; Sousa, M.J.; Santos-Buelga, S.; Ferreira, I.C.F.R. Assessment of the nitrogen fertilization effect on bioactive compounds of frozen fresh and dried samples of Stevia rebaudiana Bertoni. Food Chem. 2018, 243, 208-213. [CrossRef]

21. Dias, A.; Neto, D.A.; Menezes, R.V.; Gheyi, H.R.; Conceição, P.C.; Mitsue, A.; Cova, W.; Ribas, R.F.; Ribeiro, M.D.O. Salt-induced changes in solutes, pigments and essential oil of two basil (Ocimum basilicum L.) genotypes under hydroponic cultivation. Aust. J. Crop Sci. 2019, 13, 1856-1864.

22. Fraser, D.P.; Sharma, A.; Fletcher, T.; Budge, S.; Moncrieff, C.; Dodd, A.N.; Franklin, K.A. UV-B antagonises shade avoidance and increases levels of the flavonoid quercetin in coriander (Coriandrum sativum). Sci. Rep. 2017, 7, 1-17. [CrossRef]

23. Spréa, R.M.; Fernandes, A.; Calhelha, R.C.; Pereira, C.; Pires, T.C.S.P.; Alves, M.J.; Canan, C.; Barros, L. Chemical and bioactive characterization of the aromatic plant Levisticum officinale W.D.J. Koch: A comprehensive study. Food Funct. 2020, 11, 1292-1303. [CrossRef]

24. Dumas, Y.; Dadomo, M.; Di Lucca, G.; Grolier, P. Effects of environmental factors and agricultural techniques on antioxidant content of tomatoes. J. Sci. Food Agric. 2003, 83, 369-382. [CrossRef]

25. Ibrahim, M.H.; Jaafar, H.Z.E.; Karimi, E.; Ghasemzadeh, A. Impact of Organic and Inorganic Fertilizers Application on the Phytochemical and Antioxidant Activity of Kacip Fatimah (Labisia pumila Benth). Molecules 2013, 18, 10973-10988. [CrossRef] [PubMed]

26. Prachayasittikul, V.; Prachayasittikul, S.; Ruchirawat, S.; Prachayasittikul, V. Coriander (Coriandrum sativum): A promising functional food toward the well-being. Food Res. Int. 2018, 105, 305-323. [CrossRef] [PubMed]

27. Chahal, K.K.; Singh, R.; Kumar, A.; Bhardwaj, U. Chemical composition and biological activity of Coriandrum sativum L.: A review. Indian J. Nat. Prod. Resour. 2017, 8, 193-203.

28. Nurzyńska-Wierdak, R. Essential oil composition ofthe coriander (Coriandrum sativum L.) herb dependingon the development stage. Acta Agrobotanica 2013, 66, 53-60. [CrossRef]

29. Telci, I.; Toncer, O.G.; Sahbaz, N. Yield, Essential Oil Content and Composition of Coriandrum sativum Varieties (var. vulgare Alef and var. microcarpum DC.) Grown in Two Different Locations. J. Essent. Oil Res. 2005, 18, 189-193. [CrossRef]

30. Zeng, Z.; Meng, C.; Ye, X.; Zeng, Z. Analysis of Volatile Components of Adenosma indianum (Lour.) Merr. by Steam Distillation and Headspace Solid-Phase Microextraction. J. Chem. 2013, 2013, 545760. [CrossRef]

31. Raal, A.; Arak, E.; Orav, A.; Kailas, T.; Müürisepp, M. Composition of the Essential Oil of Levisticum officinale W.D.J. Koch from Some European Countries. J. Essent. Oil Res. 2008, 20, 318-322. [CrossRef] 